Canadian University Music Review

Canadian University Music Review

Revue de musique des universités canadiennes

\title{
God, Desire, and Musical Narrative in the Isorhythmic Motet
}

\section{Susan Fast}

Volume 18, numéro 1, 1997

Crossing Borders: Interdisciplinary Studies by Canadian Scholars Franchir les frontières : études interdisciplinaires de chercheurs canadiens

URI : https://id.erudit.org/iderudit/1014818ar

DOI : https://doi.org/10.7202/1014818ar

Aller au sommaire du numéro

Éditeur(s)

Canadian University Music Society / Société de musique des universités canadiennes

ISSN

0710-0353 (imprimé)

2291-2436 (numérique)

Découvrir la revue

Citer cet article

Fast, S. (1997). God, Desire, and Musical Narrative in the Isorhythmic Motet. Canadian University Music Review / Revue de musique des universités canadiennes, 18(1), 19-37. https://doi.org/10.7202/1014818ar
Résumé de l'article

This article examines the relationship between late Medieval narrative structure in French literature and music (specifically the isorhythmic motet) and how that structure was shaped by deeply held beliefs within Medieval culture, including the idea that a person's identity and desires were directed by God. A detailed analysis of the motet De bon espoir/Puis que la douce rousee/Speravi by Guillaume de Machaut is made to support the argument.
All Rights Reserved (C Canadian University Music Society / Société de musique des universités canadiennes, 1997
Ce document est protégé par la loi sur le droit d'auteur. L'utilisation des services d'Érudit (y compris la reproduction) est assujettie à sa politique d'utilisation que vous pouvez consulter en ligne.

https://apropos.erudit.org/fr/usagers/politique-dutilisation/ 


\title{
GOD, DESIRE, AND MUSICAL NARRATIVE IN THE ISORHYTHMIC MOTET
}

\author{
Susan Fast
}

In her book The Romance of the Rose and Its Medieval Readers, Sylvia Huot asks with respect to the work of Guillaume de Machaut, "where is the possibility for a legitimate and fruitful love, or for a learned and respectable love poetry? what sort of literary language and what sort of music are appropriate to the discourse of love?" Huot, a literary historian, is perhaps unaware that until recently the question about a music appropriate to the discourse of love would not have been entertained by most musicologists, since in order to attempt an answer we must engage in what John Van Engen calls "the subjectivity inevitably present in all interpretation"; ${ }^{2}$ we must look at the relationships between notes and then beyond, to what those relationships divulge about the people who made them, or the society in which those relationships made sense, questioning, in other words, the musical choices made archaeologically. While there is now much critical engagement of this sort about music from the Renaissance onward, it has barely touched studies of Medieval music. As Don Randall pointed out a few years ago:

The prevailing view of early music history ... has strongly discouraged ... largely on the grounds of anachronism, the enterprise most likely to undermine it: criticism. Criticism was the invention of later ages and was to be practised, therefore, only on later music. ${ }^{3}$

This has not deterred scholars of the Middle Ages in fields other than music. Medieval literature is being rethought in light of recent developments in

1 Sylvia Huot, The Romance of the Rose and Its Medieval Readers: Interpretation, Reception, Manuscript Transmission (Cambridge: Cambridge University Press, 1993), 241. For assistance with the present paper, I extend my thanks to Simon Wood, who prepared the musical examples. This paper was read at the meetings Border Crossings: Future Directions in Music Studies, University of Ottawa, 8-11 March 1995; the 23rd Conference on Medieval and Renaissance Music, University of Southampton, 5-9 July 1996; and at a graduate student colloquium at the University of Western Ontario, 8 March 1997. I am grateful to those who were present for their useful comments and to the anonymous reviewers of the essay for their valuable suggestions for improvement.

2John Van Engen, "Agenda Paper: The Future of Medieval Studies," in The Past and Future of Medieval Studies, ed. John Van Engen (Notre Dame, Ind.: Notre Dame University Press, 1994), 4.

3Don M. Randall, "Music and Poetry, History and Criticism: Reading the Fifteenth-Century Chanson," in Essays in Musicology: A Tribute to Alvin Johnson, ed. Lewis Lockwood and Edward Roesner (New York: American Musicological Society, 1990), 57. Interestingly, the charge of anachronism applies to formalist analyses as well. Daniel Leech-Wilkinson addresses this issue in his article "Machaut's Rose, lis and the Problem of Early Music Analysis," in Music Analysis 3 (1984): 9-28, in which he defends the application of analytical techniques from later periods to Medieval music, stating that "analyses of surviving works, while taking careful account of what we know of period techniques, have to proceed from, and to seek to explain, what we currently see and hear in the music" (p. 9). 
literary and feminist theory ${ }^{4}$ and even the methodology and aims of that most traditional enterprise in which Medievalists engage, philology, are being questioned in the wake of postmodern thought. ${ }^{5}$ But in music, aside from a few exceptions, those practising criticism have dealt with repertories after 1400 , and the examples from before 1600 are few and far between. ${ }^{6}$

My project here is to ask Sylvia Huot's question of what may, at first, seem a rather unlikely genre of Medieval music for this inquiry, the isorhythmic motet, and in so doing to echo Randall's plea that "some kinds of criticism of works from what we have been pleased to call the Middle Ages and the Renaissance will repay our efforts by opening new aspects of these works to us." " It may also help those outside the discipline of music - for example literary scholars such as Huot and others who engage themselves with Machaut's poetry but not with that poetry as it is set to music - appreciate how integral a part of the cultural fabric music is. ${ }^{8}$

I say that the motet is an unlikely site for this inquiry because the Medieval conception of music as sounding number is perhaps nowhere better played out

4A special issue of Speculum was recently devoted to "Studying Medieval Women: Sex, Gender, Feminism" (April 1993); several interesting volumes of criticism have appeared in the last few years, among which are The New Medievalism, ed. Marina S. Brownlee, et al. (Baltimore: Johns Hopkins University Press, 1991), which includes essays under the rubrics of "New Philology," "Literary Anthropology," and "Authority and History"; Medieval Texts and Contemporary Readers, ed. Laurie A. Finke and Martin B. Shichtman (Ithaca, N.Y.: Cornell University Press, 1987), with a useful introductory essay entitled "Critical Theory and the Study of the Middle Ages," and further essays that explore aspects of deconstruction, intertextuality and reader-response theories with respect to medieval literature.

5David Hult, "Reading it Right: The Ideology of Text Editing," in The New Medievalism, 113-30. See also The Future of the Middle Ages: Medieval Literature in the 1990s, ed. William D. Paden (Gainesville, Fl.: University Press of Florida, 1994).

6Randall has also written "Dufay the Reader," in Music and Language, Studies in the History of Music (New York: Broude Brothers, 1983), 38-78. The first part of Leo Treitler's article in Musicology and Difference focuses a discussion of gender dualities in music on the different ways in which Gregorian (depicted as masculine) and Old Roman chant (feminine) have been written about. Ultimately, however, Treitler is wary of a criticism, not only of "early," but any music, that deals with musical meanings, believing this to be too arbitrary. See "Gender and Other Dualities of Music History," in Musicology and Difference, ed. Ruth Solie (Berkeley: University of California Press, 1993), 23-42. John Shepherd has made a substantial analysis of plainchant as he perceives its structure to imply the "world sense of early medieval [feudal] society" in "Functional Tonality: A Basis for Musical Hegemony," in Music as Social Text (Cambridge: Cambridge University Press, 1991), 96-127. See also my "Bakhtin and the Discourse of Late Medieval Music Theory," Plainsong and Medieval Music 5, no. 2 (Fall 1996): 175-91. Gary Tomlinson's Music in Renaissance Magic: Toward a Historiography of Others (Chicago: University of Chicago Press, 1993) is an exemplary work of criticism, as is Bruce Holsinger's essay, "The Flesh of the Voice: Embodiment and the Homoerotics of Devotion in the Music of Hildegard of Bingen," Signs 19, no. 1 (Autumn 1993): 92-125, and the paper he delivered at the November 1995 meeting of the American Musicological Society, "Desiring Leonin: Music and Sexual Dissidence in Northern France, ca. 1200."

7 Randall, "Music and Poetry," 73.

8 Leo Treitler has recently lamented the "lack of awareness within Medieval studies outside my field about the historical materials that abound in the domain of music and about what the interpretation of those materials can contribute to the understanding of medieval culture." "Inventing a European Music Culture - Then and Now," in The Past and Future of Medieval Studies, 344. 
than in this genre, which has given rise to a discourse focused in large part on matters related solely to the complexity of its structure. In The New Grove Dictionary of Music and Musicians, the motet is described as "a rigorously logical concept of marvellous daring" designed "proportionately to unfold, demonstrate and articulate the fundamental numerical theme given by the tenor." 9 The metalanguage of isorhythm (and isomelism, isoperiodicity) used to articulate the structural principles of the motet is a product of modern, not Medieval, thought, developed by German musicologists who were pioneers in the formalist thinking about music that has so dominated the discipline in this century. ${ }^{10}$ The other peculiarity of this genre, its polytextuality, has recently begun to be subjected to sympathetic analysis, mostly by literary historians, but it was long dismissed as part of the intellectual elitism of the composers, who were thought to revel in complexities that were beyond the understanding (or hearing) of most. Christopher Page has begun to dismantle this view of the motet for the thirteenth century, offering a new translation and reinterpretation of the only Medieval treatise to deal with the subject, Johannes de Grocheio's De musica. Page challenges the idea that the makers and consumers of thirteenth-century motets were a small intellectual elite, thereby recovering for the genre a wider sphere of influence, which is significant for the analysis I give below. ${ }^{11}$

Sylvia Huot has done much in her recent work towards bringing us closer to an understanding of polytextuality in the motet. Beyond linking the poems of the upper voices with the tenor thematically, which musicologists had already done, albeit in a rather simplistic fashion, Huot argues for a thoroughly intertextual interpretation, for reading one text in light of the other, so that their meanings are intertwined. She proposes that through polytextuality "tensions that lie beneath the surface of romance or chanson are hidden no longer: in the juxtaposition of voices and registers the interplay of conflicting emotions and perspectives has become a poetic principle."12

The work that has been done concerning the correlation between text and music in the motet has been centred on structural analysis of poetry and music, ${ }^{13}$ or on an examination of "word painting," both in terms of supplying local examples of the relationship between words and notes, ${ }^{14}$ and also more

9Ernest Sanders, "Motet," The New Grove Dictionary of Music and Musicians, 20 vols., ed. Stanley Sadie (London: Macmillan, 1980) 12:619-20.

10 The term was coined by Friedrich Ludwig in 1904 and his ideas on the isorhythmic motet were subsequently taken up first by Heinrich Besseler and then Jacques Handschin. Sanders, "Isorhythm," The New Grove Dictionary of Music and Musicians, 9:353.

11 Christopher Page, "Johannes de Grocheio on Secular Music: A Corrected Text and a New Translation," Plainsong and Medieval Music 2(1993): 17-41. See also Page's discussion of the audience for the motet in his book Discarding Images: Reflections on Music and Culture in Medieval France (Oxford: Oxford University Press, 1993).

12Sylvia Huot, "Polyphonic Poetry: The Old French Motet and Its Literary Context," French Forum 14 (1984): 275.

13See for example Georg Reichert, "Das Verhältnis zwischen musikalischer und textlicher Struktur in den Motetten Machauts," Archiv für Musikwissenschaft 3, no. 4 (1956): 198-216. Reichert is concerned with the correspondence of the form of the texts with the isorhythmic structure.

14For examples see the dissertation by Beverly Jean Evans, The Unity of Text and Music in the Late 
broadly to determine how the large-scale structure of a piece correlates to the meaning of the text(s). A recent example of the latter is Margaret Bent's analysis of Machaut's Faus samblant motet, in which she links the idea of deception embodied by faux semblant (the character of "false seeming" in the Roman de la rose) to the textual theme of the tenor, which is taken from the biblical story of Jacob, full of double meanings and deception, and to the duplicitous manner in which the musical structure can be construed..$^{15}$ Bent's brilliant analysis is, however, based almost exclusively on numerological decoding (the total number of breves in the piece, how many of these appear in each talea and the varied way in which they can be grouped together within and among taleae on the basis of rhythmic patterns; the number of words in each poem, how these are distributed with respect to the music, and so on). It and other studies of this kind are hermeneutic insofar as they try to account for the way in which certain musical gestures seem to reflect the semantic content of the texts, but they do not attempt to interpret beyond this, to try to explain how the musical/textual matrix reflects in general on cultural practices. I wish to propose a different paradigm through which we might understand the motet, which takes Huot's intertextual analyses of the poetry as one point of departure, formalist analysis of the music as another, and which is then framed by theories of Medieval narrative structure and beyond to deeper structures within late Medieval French culture. I will begin with an explication of the latter, and then move to a close reading of one of Machaut's motets, De bon espoir/Puis que la douce/Speravi, through which this homology between musical and narrative structure can be drawn. During the analysis I will return to Huot's question of the appropriateness of this musical discourse to love. I should state at the outset that what I intend to do in this analysis is simply to "open a hermeneutic window" as Lawrence Kramer has said; ${ }^{16}$ obviously, much more extensive and refined analysis is required.

Historians of Medieval literature pointed some time ago to two related structural phenomena widely found in Medieval narrative, which they have termed narrative interlacing and bifurcation or bipartite (or tripartite, etc.) structure respectively. ${ }^{17}$ Both techniques are found, as William Ryding points out, in Chrétien de Troyes' romance Le conte du Graal, a few examples of which will suffice to acquaint the reader with the manner in which these techniques

Thirteenth Century French Motet: A Study of Selected Works From the Montpellier Manuscripts Fascicle VII (Ph.D. dissertation, University of Pennsylvania, 1983), which discusses the importance of the text's structure in determining musical structure; and also some of the essays in Musik und Text in der Mehrstimmigkeit des 14. und 15. Jahrhunderts (Kassel: Bärenreiter, 1984), which deal in various ways with the intersection between text and music in this repertoire.

15Margaret Bent, "Deception, Exegesis and Sounding Number in Machaut's Motet 15," Early Music History 10 (1991): 15-27.

16Lawrence Kramer, Music as Cultural Practice, 1800-1900 (Berkeley: Univerity of California Press, 1990), 5-11.

17 The history of scholarly views concerning the structure of Medieval narrative is summarized by William W. Ryding, Structure in Medieval Narrative (The Hague: Mouton, 1971), 9-37. 
operate (I should note that I might have chosen from many other Medieval works, both earlier and later, which exhibit these techniques - this one is not the earliest, the best, or otherwise unique). In the first part of this tale, a central character, Perceval, leaves home in order to become a knight. This event sets into motion a series of episodes which Ryding describes as follows:

Perceval leaves his mother to go in search of the chivalric life and Arthur's court. She falls to the ground, but neither Perceval nor the reader knows that she has died until after he leaves the Grail Castle, when his cousin accuses him of causing his mother's death. Again, after leaving home, he breaks in on a girl in a tent, eats her cakes, kisses her, and then rides off. Later, after talking to his cousin and learning of his mother's death, he meets the same maiden being brutally treated by her jealous lover, L'Orguelleus de la Lande. ${ }^{18}$

What Ryding doesn't mention in his description is that L'Orguelleus de la Lande is jealous because he has learned of Perceval's earlier visit to the maiden's tent, and has accused her (it would seem mistakenly) of making love with him. ${ }^{19}$ This information ties her miserable treatment by L'Orguelleus directly to Perceval and his episode with her at her tent.

The examples of narrative interlacing continue, as Ryding explains:

Two other matters are begun before Perceval's arrival at the Grail Castle: He becomes involved with Blanchefleur, defends her against Clamadeu des Iles, and spends a night in her arms; secondly, he arrives at Arthur's court and then leaves to win the armor of the Red Knight. These matters too are resolved [only] after the visit to the Grail Castle. ${ }^{20}$

In fact, after he spends the night with Blancheflor, he leaves to find out what has happened to his Mother. On his way to her, he learns that she has, indeed, died, and he abandons his journey. In a remarkably complex segue, Chrétien returns to the Blancheflor episode: as Perceval turns back from the journey to

18 Ibid., 140.

19Chrétien de Troyes, Le conte du Graal, ed. Charles Méla (Paris: Librarie générale française, 1990), 279-81.

L'Orgueilleus: "Ecoute-moi donc et tu vas entendre l'histoire.

Récemment encore, j'étais allé aux bois

et $\mathrm{j}$ 'avais dans un pavillon de tente

laissé la demoiselle que voici.

Je n'aimais d'autre créature qu'elle.

Voilà que d'aventure survint,

en ces lieux, un jeune Gallois.

J'ignore tout du chemin où il allait,

mais il réussi à lui prendre un baiser

de force, elle-même me l'a avoué,

et si c'est bien malgré elle qu'il lui a pris un baiser,

ne devait-il pas, de toutes façons, faire d'elle ensuite sa volonté?

Oh, oui, personne n'irait jamais croire

qu'il lui a pris un baiser sans lui faire plus,

car une chose entraîne l'autre."

20Ryding, Structure in Medieval Narrative, 141. 
his Mother, he sees a falcon kill a goose, who sheds three drops of blood on the white snow. "The blood and the snow together," Chrétien writes, "reminded Perceval of the fresh hue on his beloved [Blancheflor's] face and he mused until he forgot himself."21

There is a larger narrative jolt in this récit, however, which comes when Perceval as central subject is completely dropped "at the height of his glory" as a knight ${ }^{22}$ and a new subject, Gawain, is introduced and developed instead: Chrétien makes this transition, if one can call it that, by telling the reader "Des aventures qu'il [Gawain] a trouvée, vous allez m'entendre parler un long moment." 23 Perceval does not appear again for another fifteen hundred lines of text, ${ }^{24}$ when he is brought back by the narrator who says that he will now stop Gawain's story and take up Perceval's again:

De mon seignor Gauvain se test

Li contes ici a estal

Si Parlerons de Perceval,

Perceval, ce conte l'estoire.

A si perdue la memoire

Que de Deu ne li sovient mais. ${ }^{25}$

And indeed, Perceval's story is now resumed.

Not so long ago, the characteristics of narrative interlacing and bipartite structure were considered a great failing of much Medieval literature, but these texts are viewed more sympathetically now as adhering to organizational principles different from teleologically-conceived modern narrative, based on Aristotelian principles, that followed in the sixteenth century. ${ }^{26}$ Narrative interlacing attempts to pull the various episodes of a piece into a contemporaneous whole, to make it seem as though they are occurring simultaneously, not sequentially. ${ }^{27}$ In Le conte du Graal the significance of the bipartite structure has been described as an expression of "contrasting and deliberately juxtaposed tableaux, Gawain's adventures being purely mundane, those of Perceval informed by a contrasting ethical and religious spirit." ${ }^{28}$ It has been remarked that "the full meaning of [the characters'] experiences depends on their juxtaposition with those of the others" in this kind of narrative technique. ${ }^{29}$ Early Medieval stories such as Beowulf, La vie du Saint Alexis and Chrétien's other narratives operate on a similar structural principle, ${ }^{30}$ but it became a tendency "especially from the thirteenth century on" 31 and almost

21 Ibid.

22 Ibid.

23 Le conte du Graal, 345.

24Ryding, Structure in Medieval Narrative, 141.

25Quoted in ibid., 141-42.

26Ibid., 9-10.

27 Evelyn Birge Vitz, Medieval Narrative and Modern Narratology: Subjects and Objects of Desire (New York: New York University Press, 1989), 119.

28Ryding, Structure in Medieval Narrative, 27.

29 Ibid., 152.

30Ibid., 25-27. 
exclusively in France. This is, of course, the precise historical moment and locale for the birth of the motet.

That there is more than one central subject in Le conte du Graal is certainly interesting: in fact, Perceval and Gawain are by no means the only subjects in this narrative - many others come into play in this story as well - and again, one senses that it is through the development of one character that we come to understand another one more fully. But the literary historian Evelyn Birge Vitz points to a phenomenon that is perhaps of greater consequence, the presence of a force we might not initially recognize as a true subject, but must surely be so considered: God. ${ }^{32}$ Each action of the narrative is controlled by God's will, or what God desires to have transpire. For example, Perceval's Mother pleads with him not to become a knight, arguing that he is her only consolation, that God has left her no other joy: "Vous étiez la seule consolation, le seul bien qui me restrait, car je n'avais plus personne des miens. Dieu ne m'avait rien laissé d'autre qui pût faire ma joie et mon bonheur." ${ }^{33}$ When a town is ravaged by hunger after battle, a ship carrying food and other provisions arrives, "as God pleases" safely to aid those affected: "un coup de vent avait chassé en mer un chaland, qui avait sa charge de blé et qui était rempli d'autres vivres, et Dieu a voulu qu'il aborde intact et sauf devant la citadelle." 34 When Gawain's adventures break off and Perceval's story is resumed, he is found contemplating his five-year neglect of God, after which he turns to a holy man to repent for this sin, and learns from the Sage that he has only been watched upon by God during this time his mother had prayed to God on his behalf: "si elle ne t'avait recommandé à Dieu Notre Seigneur, sache-le! Mais sa prière eut une telle vertu que Dieu t'a pour elle regardé, te préservant de la mort et de la prison." 35 Aside from controlling the action in these ways, God is simply a constant presence in this story, His name is evoked in almost every line: "for the mercy of God," "in God's name," "so help me God," making it impossible to forget what a powerful and omnipresent force God was in Medieval society. As Vitz points out, we might dismiss these references to God as nothing more than rhetorical figures, but she urges

that we take seriously the Medieval cliche. ... In other words, this text is, at some level, explicitly God's story, God's work; this mysterious plot, these events are God's miracles. God is not only its author, but its true subject. It is He whose will - whose desire, whose object - determines the action. ${ }^{36}$

It should not be surprising for this to be the case in a profoundly Christian society; that even a story that does not in any direct way involve a sacred theme should be in the end completely regulated by the divine, should have as its ultimate subject God. This omnipresence of God in Medieval life and thought

31 Vitz, Medieval Narrative and Modern Narratology, 100.

32Ibid., 117-20.

33 Le conte du Graal, 57.

34 Ibid., 191.

35 Ibid., 451.

36Vitz, Medieval Narrative and Modern Narratology, 118. 
had an effect not only on the shape of narrative, but also on the way in which characterisation of human subjects was made, which Vitz argues is more on a vertical than a horizontal axis. Medieval characters are described as having certain qualities that liken them to past figures who are held up to be models and icons, to Saints or the church Fathers, for example; there is little interest in qualities that set someone apart, that make them individual, deviant, aberrant, that depart from the norm in some way, which was to become central to characterization in modern literature. As Vitz says with respect to this type of characterization:

the influence of Christianity is, without any doubt, significant. In particular psychology in this period is not yet secularized: it is hardly distinct from theology. Indeed, the men who write about "psychology" - that is human nature, the faculties, the appetites - are primarily theologians. And their basic concern is not with individuation - horizontal differentiation among individuals - but with salvation and damnation, the rise and fall of souls, their vertical movement with relation to God. And this basic orientation seems to have pervaded almost all Medieval thinking about human character and change, psychological movement is either exaltation or abasement ... it is progress or regress ...37

Vitz also links the treatment of desire and causality in Medieval texts to the regulation of the narrative by God. Medieval characters are certainly motivated by desires, which she defines broadly as "that dissatisfaction or need, on the part of a character, which provides narrative stimulus or 'causal energy' in the text,"38 but their desires are dealt with in fundamentally different ways than in modern narrative. Vitz suggests that Medieval authors drew, probably subconsciously, on the Augustinian model in which "causality ... is essentially a divine prerogative ... human causality is never anything but 'secondary." 39 While characters in Medieval narrative may be motivated by desires of their own, how these desires are satisfied (or not) is not under the individual's control.

The motet De bon espoir/Puis que la douce/Speravi by Guillaume de Machaut conforms to our expectations of the ars nova motet in many respects (the score is reproduced here in full).$^{40} \mathrm{It}$ is for three voices, all of which are isorhythmic. The upper two voices have French, secular texts and the tenor, textless save for an identifying rubric, is taken from a piece of plainchant.

As has been pointed out by others, the themes of the triplum and duplum poems correlate: they explore one of the central ideas of amour courtois, the

37Ibid., 19.

38 Ibid., 176.

39 Ibid., 179.

40 This analysis is based on the edition by Leo Schrade, Polyphonic Music of the Fourteenth Century, vol. 3, (Monaco: Éditions de l'Oiseau-Lyre, 1956), 119-22, copyright, Éditions de l'OiseauLyre, S.A.M., Monaco, 1977. The score is reproduced here by kind permission of the publisher. Readily available translations of the texts can be found in David F. Wilson, Music of the Middle Ages: An Anthology for Performance and Study (New York: Schirmer, 1990), 216. 
Puis que la douce rousee
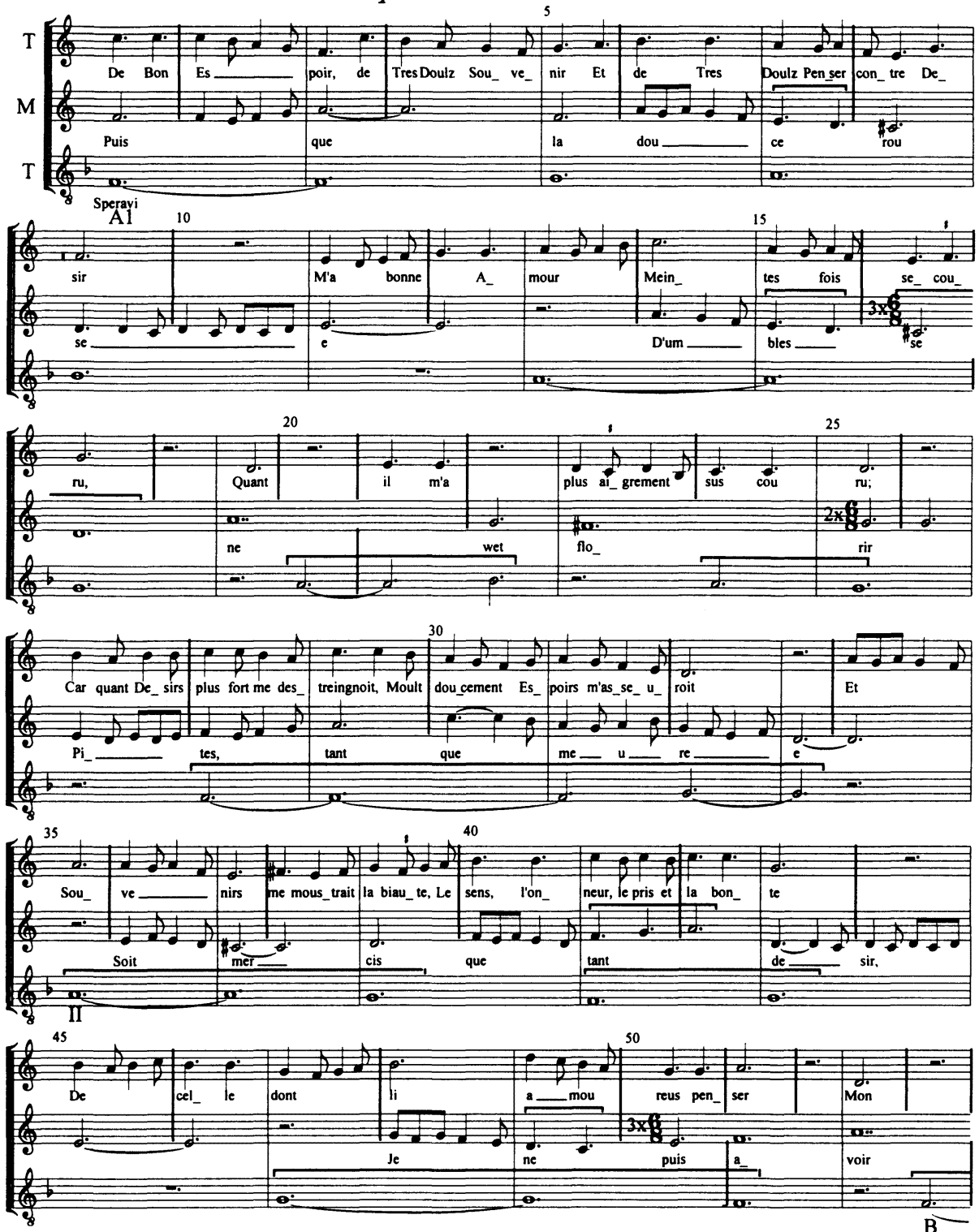

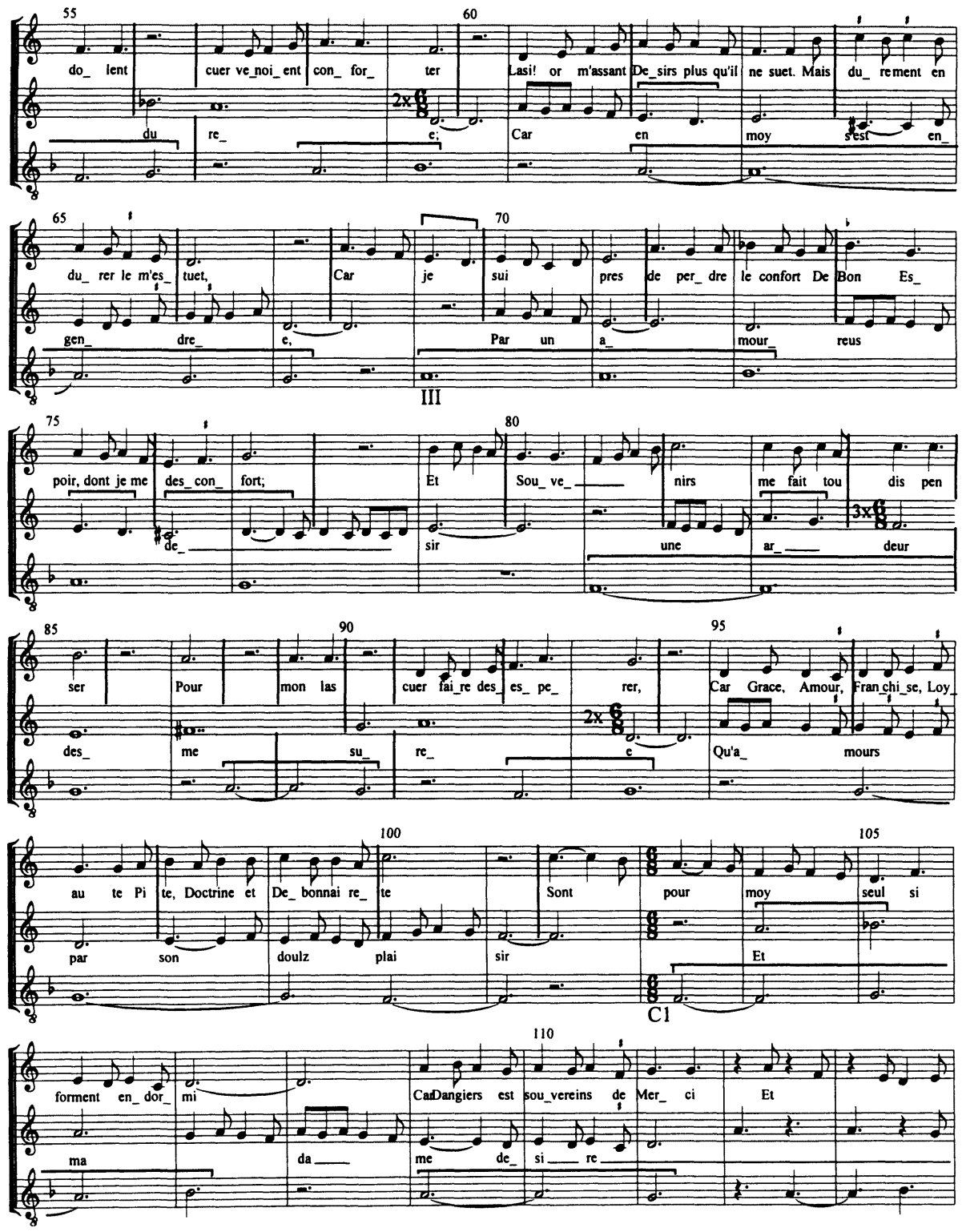
115

120

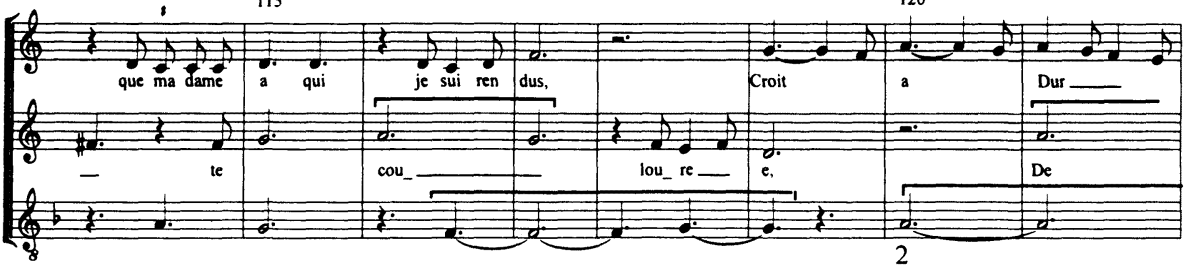

125

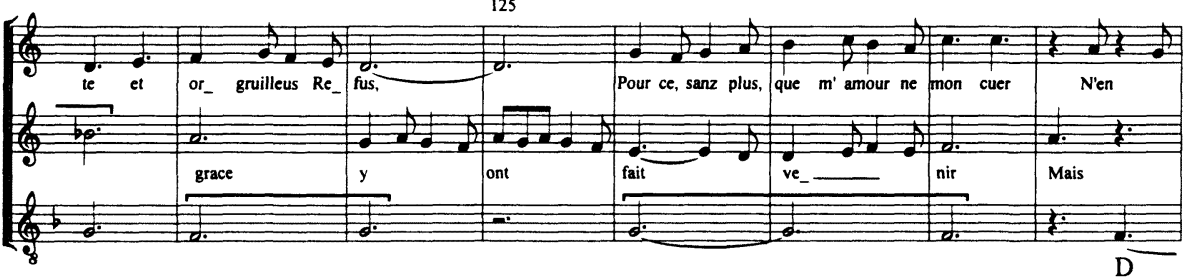

130

135

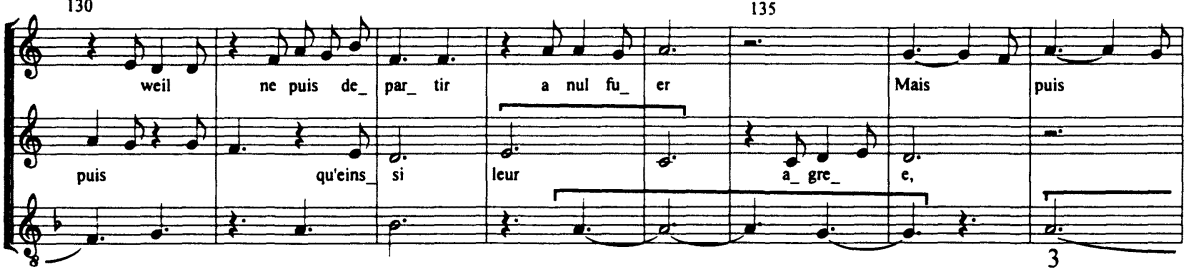

140

145

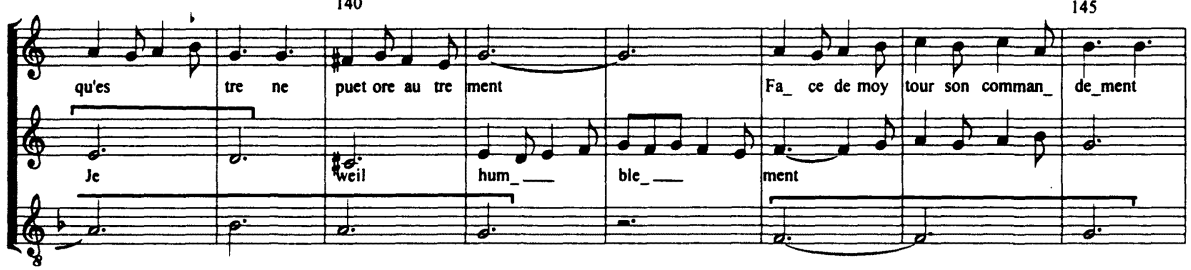

150

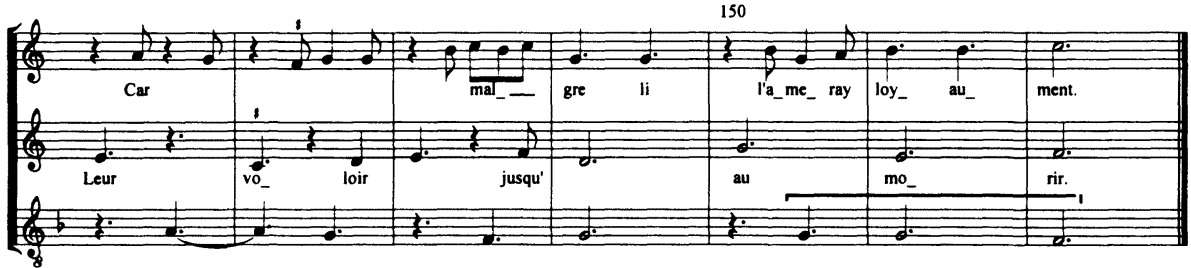


unrequited lover who chooses to suffer through continued loyality to his lady, the object of his desire. It has been remarked by Gilbert Reaney how the word in the tenor (speravi - I have hoped) "fits very well" with this theme since amorous hope drives the protagonist of the triplum poem. ${ }^{41}$ This remark provides a good starting point for further analysis of the three texts and their interrelationships. The poem of the triplum describes a subject who expresses overwhelming desire for a lady who refuses his love; he relies on Hope to comfort him in this situation as he has done in the past, but is so stricken by love this time that he feels he might lose the comfort of Hope altogether. The poem of the motetus offers a different view: here there is also great amorous desire, but no overt refusal on the part of the woman. The subject of this poem suffers from "an amorous desire" that his lady has "graciously made to enter [his] heart" and he wants "to suffer humbly." Hope is not brought into the picture, but Humility is twice invoked.

The tenor comes from a chant for the first Sunday after Pentecost (Psalm 12); the subject of this text does not fit with the upper-voice texts so much as it contrasts the amorous hope of the triplum with hope in God, as Kevin Brownlee has pointed out. ${ }^{42}$ This subject rejoices in, sings about, his hope; here there is no suffering or despair, only celebration that springs from the fulfilment of desire. But we might also speculate on the interconnection among the representations of desire that are made. Returning to Vitz's observations about desire and causality in Medieval literature, we can note that in this context too, divine will is represented as that agent with the potential to satisfy the protagonist's desire and that this power does not lie with the subjects of the triplum and duplum poems. Further, the tenor text suggests that the fulfilment of desire can come by two means: either God can allow the protagonist to have his lady, or the protagonist can abandon his desire for earthly love and find fulfilment in his love for God instead.

It is the heroic quality of long suffering that is being celebrated in these poems, in a way that is similar to other poems in this genre. Interestingly, Christopher Page is critical of recent studies of individual motets that have, instead of dealing with the structure of the music, considered the relationship among the texts, acknowledging, for example, a thematic correlation between tenor text and those of the upper voices, or between text(s) and music. He argues that much of the poetry expresses generic sentiments and offers an analysis of the thematic correspondences between a triplum and motetus poem which, he reveals at the end of the analysis are taken from two different

41 Gilbert Reaney, Guillaume de Machaut (London: Oxford University Press, 1971), 51.

42Kevin Brownlee, "Machaut's Motet 15 and the Roman de la Rose: The Literary Context of Amours qui a le povoir/Faus samblant m'a deceu/Vidi Dominum," in Early Music History 10 (1991): 13-14. Alice V. Clark has also made an important observation with respect to the thematic interrelation of texts in Machaut's motets. She has determined that many of the motet tenors derive from chants for Lent and Holy Week which, she says "is significant, especially in an amatory context: the sorrow and pain of the lover is explicitly compared to that of Jesus on the cross, the narrator's passion with the passio of Christ. The comparison may be either straightforward or ironic, or both at once, but I believe it must be intentional" (paper given at the American Musicological Society national conference, Pittsburgh, 1992). My thanks to Dr. Clark for providing me with a copy of her paper. 
motets. ${ }^{43}$ I find the literary analyses of motets by Huot and others valuable in many ways, and bring up Page's point here only because it is not necessarily a negative criticism: it resonates perfectly with Vitz's comment concerning depictions of character in the Middle Ages, namely, that there is a certain generic quality to these depictions, that it was less important to emphasize the individual, more important to be depicted as a character type. We will find this to be the case again in the musical setting of these poems.

In this motet, then, there are really three different, but thematically related, subjects, one of which illuminates, enhances or redirects the meaning of the other in a manner characteristic of much Medieval narrative. There is also a mixture of the sacred with the profane, the presence - the omnipresence we will soon see - of God in this récit about secular love. Significantly, it is only through the possibility of music that these characteristics of Medieval narrative can be fully exploited. Through polyphony, the completely simultaneous expression of these stories is possible as it is not in written poetry or prose, despite the best efforts of interlacing by Medieval authors. However it is not only this surface structure of the music, not only the simultaneity that is important to note, but the musical details in which the narrative is most fully played out. I would like to examine these now, beginning with the tenor voice. ${ }^{44}$

The complete text of the tenor voice presents a specific subject and this subject is certainly important to the semantics of the composition, as was pointed out above; but neither the complete text of the chant, nor the complete melody were borrowed to make the tenor of the motet, only a fragment of each. Because of this one can also posit the tenor as a more generalized divine presence: the sacred foundation, ${ }^{45}$ the structural voice drawn from the stable tradition of plainchant, ${ }^{46}$ a comforting manifestation of that presence, which is literally connected to a larger whole, not only through the specific pitches of the borrowed melody but also through its modality (mode V, with its final on $\mathrm{F}$, which is the same as that of the chant). This divine subject, God, asserts power and authority over the other voices in musical terms, by moving at a much slower rate rhythmically; it asserts stability by moving in stepwise motion; it maintains its distance from the upper voices by never engaging in their rhythmic or melodic gestures and by maintaining its own range, lower than the other voices, while the upper voices sometimes cross and share rhythmic material. Both Susan McClary and Bruce Holsinger have discussed shared vocal or instrumental range within a piece as a metaphor for physical intimacy; ${ }^{47}$ in this motet, there are two further ways in which such intimacy is expressed: the upper voices share rhythmic material and through the act of

43 Page, Discarding Images, 87-88.

$44 \mathrm{~A}$ version of the chant can be found in the Graduale Triplex (Paris and Tournai: Abbaye Saint-Pierre de Solemnes, 1979, 278.

45Margaret Bent also points to the significance of the sacred tenor as the "musical and symbolic foundation of the motet," in "Deception, Exegesis and Sounding Number," 25.

46By this comment I do not mean to suggest that there was a completely unchanging body of Gregorian chant in the Middle Ages; this was, of course, not the case.

47 Susan McClary, Feminine Endings: Music, Gender and Sexuality (Minneapolis: University of Minnesota Press, 1991), 37; Bruce Holsinger, "Desiring Leonin." 
singing, the two texts merge and become one in several places (see below), all of these devices we could posit, in answer to Sylvia Huot's question, making this music "appropriate to the discourse of love." The distance between tenor and upper voices is made more pronounced if the tenor is played on an instrument instead of sung, which is the way pieces such as this are often performed today (although Christopher Page makes a strong case for all the voices being sung). ${ }^{48}$ It is striking that in the motets by Machaut and others that make use of a secular tenor melody, this tenor "will usually be equal in range and melodic motion to the other voices, forming with them an intertwining trio of equal voices," 49 suggesting a profound musical distinction in character between secular and sacred subjects in this genre. An example of this can be seen in Machaut's motet Trop plus est bele/Biauté paree/Je ne sui mie certeins, which has a secular tenor (example 1). ${ }^{50}$

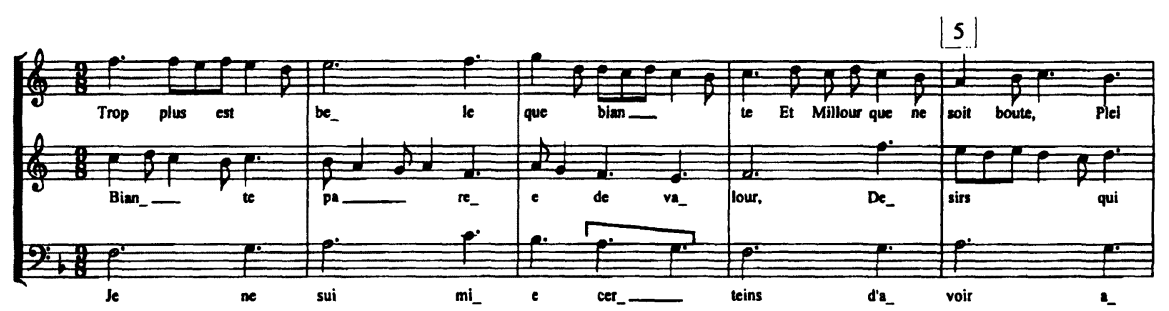

Example 1: Machaut, Trop plus est bele/Biaute paree/Je ne sui me certains, beginning. Reproduced by kind permission of Éditions de l'Oiseau-Lyre.

The upper voices are borne through their relationship to the sacred tenor in the first instance, since the pitches of that voice are given. ${ }^{51}$ The vertical sonorities created between tenor and upper voices are almost always perfect consonances, while intervals between the upper voices, and those that occur between upper voices and tenor when the tenor is sustained, may be dissonant. In other words, a change in pitch by the tenor occasions a movement to consonance by all voices. ${ }^{52}$ While dissonance (or disharmony) is allowed to exist between voices representing the secular world, and while they may create

48 Page, "Machaut's 'Pupil' Deschamps on the Performance of Music: Voices or Instruments in the Fourteenth-Century Chanson?," Early Music 5, no. 4 (October 1977): 484-91; idem, "The Performance of Songs in Late-Medieval France: A New Source," Early Music 10, no. 4 (October 1982): 410-50.

49Wilson, Music in the Middle Ages, 261; Reaney makes the same point: when a secular song is used as the tenor "the three voices blend much better....The huge length of the notes in the lower parts is less apparent," Machaut, 54.

50The motet is found in Leo Schrade, ed., Polyphonic Music of the Fourteenth Century, vol. 2 (Monaco: Éditions de l'Oiseau-Lyre, 1956), 11. Copyright, Éditions de l'Oiseau-Lyre, S.A.M., Monaco, 1977. Reproduced by kind permission of the publisher.

51 This is not to promote the old theory of "successive" composition, which stated that each upper voice must be consonant with the tenor first, and only secondarily with the other upper voice or voices. See Leech-Wilkinson, "Machaut's Rose, lis..."

52There is a striking exception in measure 5 of the Schrade edition, in which the tenor sounds a G against the motetus $F$. 
dissonance with the sacred tenor through their own movement, movement of the divine voice can only lead to consonance. These upper voices, as was noted, sometimes share the same range and rhythmic patterns, but never the same melody. They maintain separate phrase structures, beginning and ending at different times. The character of their melodies is also distinct, the motetus often moving at a slower rhythmic pace than the triplum. But this, we must remember, was a standard practice in the ars nova motet: the upper voice characteristically moved more quickly than the motetus, and so this feature is not unique to the piece under consideration. The rhythmic patterns of the upper voices sometimes interlock; in fact, the rhythmic structure of the voices is relatively static. There are a few different, short rhythmic patterns that are repeated throughout the piece, more complex, but on the same order as the earlier use of rhythmic modes. The furthest interconnection between these subjects occurs with the use of hocket, when for a moment they must articulate a single melodic idea as if they were one (mm. 112-14; 129-31; 146-48). So while there is differentiation between these two voices, these two subjects, there is also a sameness, a sameness between the two of them and between these characters and others within this musical genre.

This similarity, I would argue, echoes the generalized characterisation of subjects in Medieval narrative in several ways. Rhythmically and melodically the voices have much in common: they are not terribly different from one another, they are individuated only to a limited degree. The repetition of rhythmic motives establishes the relatively narrow boundaries in which the characterisation of these voices is going to take place. There is no breaking of these boundaries by one or another of the voices in the name of individual expression; no getting away from them in order to paint a particular word or phrase of the text in the way that later music will. ${ }^{53}$ And the patterns and relationships between these two voices occur in other motets as well. This is a variation of patterns that have been established before - they are not deviant, not individualized.

Furthermore, during a performance of the piece, we begin to hear the triplum and duplum texts not as distinct, but as a single entity. Often we hear a phrase from one text while the other pauses and vice versa, or a word from one text may be interjected into the middle of a phrase from the other text. This essentially produces a third text, one that is the aural combination of triplum and motetus, which is highly impressionistic - for example, when the triplum cadences at the end of the line "Et Souvenirs me moustroit la biaute, Le sens, l'honeur, let pris et la bonte," the motetus part continues on with the word "desir"; or the way in which we hear the triplum line "Pour mon las cuer faire desesperer" coincidentally with the motetus word "desmesuree," with individual syllables of the latter word interspersed with the text of the triplum

\footnotetext{
53 Some scholars have found instances of word painting in the motet. In this work, for example, one could point to the change in mensuration that occurs in the motetus, producing longer note values for the text "une ardeur desmesuree" and again with "Je ne puis avoir duree"; but a third time that this mensuration change occurs, the text does not correlate ("D'umblesse ne wet florir"). The changes in mensuration also come in the middle of the lines of text, not at the beginning.
} 
voice. Since in this motet the two poems offer slightly different versions of the same theme, their combination in the musical setting serves to blur distinctions between the two even further. It is also a superb example of narrative interlacing.

The tenor is not only considered to be structural because it produces the pitches on which the piece is based, but because it is organized isorhythmically. It is this imposed rhythmic structure, absent in Gregorian chant, that links the pitches of the tenor to the profane world, that makes it possible for the chant fragment to coexist with the other voices in this context. ${ }^{54}$ It is also this rhythmic structure that further develops the subjects and delineates relationships among them. The rhythmic pattern of the tenor in this piece is repeated three times at integer valor (the original rhythm) and again three times in diminution (rhythmic values cut in half). Based on this we can say that the piece bifurcates - that it has a bipartite structure. The diminution in the tenor (beginning at m. 103) does not coincide with a neat structural division of the text in the upper voices - in fact the triplum has just begun a new phrase in the previous measure; the duplum begins a new phrase the measure after the diminution begins, and the rhythmic and melodic character of the upper voices does not change until ten measures into the diminution section and then rather violently with the introduction of hocket. But the tenor has changed its character with the advent of diminution. This bears a similarity to the bifurcation of the narrative in Chrétien's grail story in that "Gawain's adventures [are] purely mundane, those of Perceval informed by a contrasting ethical and religious spirit," or the bifurcation of another Medieval récit, The Life of Saint Alexis. The first half of this story tells the Saint's biography, but the second half deals with events that occurred after his death. Some literary historians have explained this by

pointing out that author was not trying to write a biography in the ordinary sense of the word; he was trying rather to paint the saint's life in the form of a diptych, setting the imperfections and transitoriness of his earthly life over against the lasting glory of the world beyond. ${ }^{55}$

I would propose that the opposite phenomenon has occurred in Machaut's motet. When the diminution begins in the music, the tenor is still obviously recognizable as the same character through its melodic and rhythmic organization, but it is evident from its transformation through diminution that it has moved closer to the secular world of the upper voices by speeding up its rhythmic movement to coincide more closely with theirs, representing, perhaps, movement towards the fulfilment of secular desire.

The sameness of the tenor, the constant repetition of a melodic and rhythmic pattern, points to another link between Medieval narrative and this motet, that

54 I believe this interpretation, albeit slightly modified, holds from the earliest rhythmicization of chant, which occurred in the sacred polyphony of Notre Dame; this rhythmicization took place in order that the chant and newly-composed voices might be able to move together more easily.

55Ryding, Structure in Medieval Narrative, 26. 
is the lack of goal-directedness - and this is a difficult issue to address because scholars such as Daniel Leech-Wilkinson and Sara Fuller have recently argued effectively for the presence of goal-directed progressions in late Medieval music, by which they mean the movement from imperfect to perfect sonorities. ${ }^{56}$ Leech-Wilkinson shows convincingly how these progressions are operative in Machaut's rondeau "Rose, lis," for instance (example 2). ${ }^{57}$

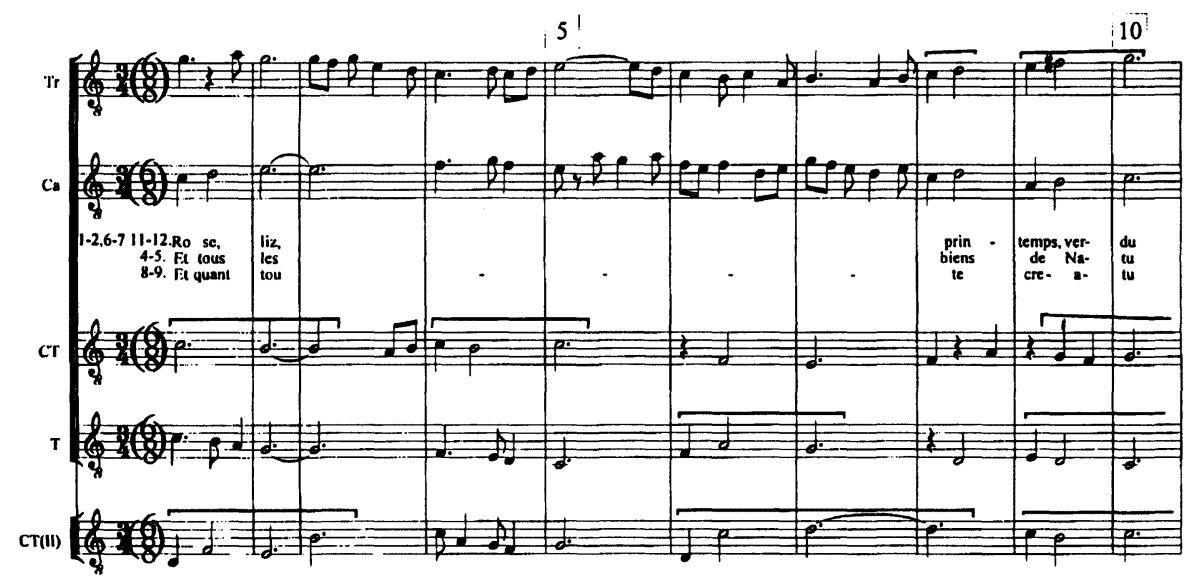

Example 2: Machaut, Rose, lis, beginning. Reproduced by kind permission of Éditions de l'Oiseau-Lyre.

The opening phrase, as Leech-Wilkinson points out, has a clear teleology, the tenor opening outward from $\mathrm{C}$ down to $\mathrm{G}$ and then to $\mathrm{C}$ below that, etc. $\mathrm{He}$ argues that the recurring rhythmic pattern in the tenor helps to propel the line forward, while harmonically, the points of arrival, for example what LeechWilkinson calls the $\mathrm{G}$ chord of measure two, also serve as points of departure: the $\mathrm{G}$ chord is comprised of a third and a sixth, and it moves towards the $F$ chord at the beginning of measure four, which is comprised of perfect intervals, a fifth and octave, and so on. Leech-Wilkinson discusses this particular harmonic movement, which he calls a II-I cadential pattern (a leading-tone cadence in other parlance), in terms of movements from "desire to fulfilment," which he says:

might stand as a symbol for the very nature of Machaut's songs, perhaps even fourteenth-century song as a whole. For the progression from conation to resolution, from desire to fulfilment is fundamental ... to the poetry and whole tradition of Courtly Love. ${ }^{58}$

56 Sara Fuller, "On Sonority in Fourteenth-Century Polyphony: Some Preliminary Reflections," Journal of Music Theory 30 (1986): 35-70 and Leech-Wilkinson, "Machaut's Rose, lis...."

57 The rondeau is found in Leo Schrade, ed., Polyphonic Music of the Fourteenth Century, vol. 3 (Monaco: Éditions de l'Oiseau-Lyre, 1956), 152. Copyright Éditions de l'Oiseau-Lyre, S.A.M., Monaco, 1977. Reproduced by kind permission of the publisher.

58Leech-Wilkinson, "Machaut's Rose, lis," 14. 
But the goal of courtly love poetry is not the fulfilment of desire, but rather the lack of fulfilment. And while the goal-directed progressions in the rondeau are undoubtedly there, if we turn back to the motet, the model of goal-directed progression works less well. I would argue that in this piece, the directed progressions are local - that they indicate momentary forward motion and not large-scale teleological progression in the sense of later, tonal music. Part of the reason for this is that directed progressions occur at the beginning and middle of phrases as well as at the end and the fact that phrase endings are, furthermore, made to seem like less of a "goal" because there is no real resting point at internal cadences - once set in motion, the voices almost never pause at the same time and there never occurs a point at which there is not at least one voice sounding. But the biggest factor against the feeling of goal directedness is the controlling movement of the tenor, which gently rises and falls, wave-like, within the narrow span of four pitches: F, G, A and B-flat, which tends to thwart strong goal-directed harmonic movement. An analogy might be drawn with the colotomic structure of gamelan music, the motet tenor acting like the slow-moving balungan, or skeletal melody, the upper voices the paraphrasing of this melody. ${ }^{59}$ In this particular motet, there is a further feature which adds to this effect and that is that the upper two voices are also isorhythmic. The upper-voice isorhythm coincides with the talea of the tenor; it has been remarked that this helps to articulate, audibly, the structure of the tenor. ${ }^{60}$ It also enhances the static quality of the composition: all three of the voices are engaged in the continual repetition, the rearticulation of the rhythmic foundation of the piece. The upper-voice isorhythm also, importantly, compromises the independence of these voices; it draws them into the power, the authority of the tenor voice, of God, the controlling subject of this narrative. All this contributes to the vertical and stationary as opposed to horizontal movement of the music. Compare this with the way in which Evelyn Birge Vitz describes the effect of narrative interlacing in a Medieval story:

Medieval narrative ... is often surprisingly like a picture in that the episodes are massed, visualizable motif clusters. ... The unity of this work is more that of the complex image than that of the récit.... We are invited by these "narrative" texts to transcend their sequentiality to see them ... as a great single spectacle. ${ }^{61}$

There is an especially intriguing moment in this regard in the diminution section, when the upper voices resist the change introduced by the tenor, but are eventually drawn into its power once again by altering their characters, even as the tenor itself is being drawn into the faster rhythmic pace of the secular world. As Vitz says: "In the case of the Medieval récit ... we can be said to have the intrusion of the idea of the divine perspective - for which change does not occur - into the human experience of change."62

$59 \mathrm{My}$ thanks to Sandra Mangsen for suggesting this parallel.

60Sanders, "Motet," 626.

61 Medieval Narrative and Modern Narratology, 119-20.

62 Ibid., 120. 
Sylvia Huot proposes that through polytextuality tensions concerning Medieval conceptions of love that usually lie hidden, for example the juxtaposition of the ideals of courtly love with those of the more explicitly sexual pastoral poems, and with divine love, are brought to the surface and articulated. The motet "as a whole elaborates a psychology of love, dramatizing the fulfilment, the prolongation, and the repression of desire," 63 in accordance, I would add, with the principles that guided the structure of later Medieval narrative, including the role of the divine and its effect on characterization. It is a dialogic genre, in which the interplay among the subjects of the poems is as important as the individual poems themselves. These tensions are not only articulated poetically but musically: in the limited individuation of the upper voices, their interaction, in the pull between sacred and secular musical characterization, in the musical characterization of the divine voice itself.

\begin{abstract}
This article examines the relationship between late Medieval narrative structure in French literature and music (specifically the isorhythmic motet) and how that structure was shaped by deeply held beliefs within Medieval culture, including the idea that a person's identity and desires were directed by God. A detailed analysis of the motet De bon espoir/Puis que la douce rousee/Speravi by Guillaume de Machaut is made to support the argument.
\end{abstract}

